\title{
ENVIRONMENTAL EFFECT OF DELAY TIME IN OPEN PIT BLASTING
}

\author{
Vedat DENIZ* \\ Engineering Faculty, Hitit University, 19030, Turkey, vedatdeniz@hitit.edu.tr \\ (iD) https://orcid.org/0000-0003-4098-959X \\ Orçun Tugay DENIZ \\ Department of Mining Engineering, Hacettepe University, 06800, Turkey, tugayorcun@gmail.com \\ (iD) https://orcid.org/0000-0003-4262-165X \\ Received: 07.01.2018, Accepted: 16.05.2018 \\ *Corresponding author \\ Research Article \\ DOI:10.22531/muglajsci.375843

\begin{abstract}
In this study, the effect on the ground vibration values of two different surface delay times (17 ms and $25 \mathrm{ms)}$ in between holes in the blasting operations in the quarry belong to the Corum Votorantim Cement Corporation were investigated. The vibration measurements of the blasting in both surface delay times have been taken from different distances, and the relationship between the scale distance (SD) and the peak particle velocity (PPV) was investigated. From the test results of the two different surface delay times, not only have there been different results obtained in the relationship between the scale distance and the peak particle velocity but also different results on the frequency have been obtained, the amplitude and the duration of the vibration. From the results of blasting test, the vibration amplitude obtained during the surface delay of $25 \mathrm{~ms}$ is higher than the surface delay of $17 \mathrm{~ms}$, and It has been found that the use of a surface delay of $25 \mathrm{~ms}$ for this quarry will has less damage potential.
\end{abstract} \\ Keywords: Blasting, environmental effect, delay time, vibration, peak particle velocity
}

\section{AÇIK OCAK PATLATMASINDA GECİKME ZAMANININ ÇEVRESEL ETKİSİ}

\section{$\ddot{0} \mathbf{z}$}

Bu çalışmada, Çorum Votorantim Çimento A.Ş. ait kalker ocağındaki patlatma çalışmalarında delikler arası iki farklı yüzey gecikme süresinin (17 ms ve 25 ms'lik) ortaya çıkan yer sarsıntısı değerleri üzerinde etkisi araştırılmıştır. Her iki yüzey gecikme aralığında yapılan atımların titreşim ölçümleri değişik mesafelerden kayıt altına alınarak sahanın ölçekli mesafe (SD) ve maksimum parçacık hızları (PPV) ilişkileri araştırılmıştır. Íki farklı yüzey gecikme aralı̆̆ı için yapılan test sonuçlarından; hem titreşim frekansl, genliği ve sürelerinde farklı sonuçlar elde edilirken, hem de ölçekli mesafeler ve maksimum parçacık hızları arasında farklı ilişkiler elde edilmiştir. Patlatma testlerinin sonuçlarından, 25 ms'lik yüzey gecikmesi kullanımı sırasında elde edilen titreşim genliği, 17 ms'lik yüzey gecikmesinden daha yüksektir ve bu ocak için 25 ms'lik yüzey gecikmesi kullanımıyla daha az hasar potansiyeline sahip olacağı bulunmuștur.

Anahtar Kelimeler: Patlatma, çevresel etki, gecikme aralığı, titreşim, maksimum parçacık hızı

Cite

Deniz, V., Deniz, O.T., (2018). "Environmental effect of delay time in open pit blasting”, Mugla Journal of Science and Technology, 4(1), 5-10.

\section{Introduction}

In recent years, mining and quarrying have been exposed to complaints from discomforts such as ground vibrations and air shocks by the blasting event due to housing dwellings near the mine and quarry fields. Types and quantities of explosives, and the blasting patterns are an important factor in efficiency for a quarry, while ignition systems are becoming more important in terms of environmental impacts such as ground vibration and noise (air shock) and safety [1-2].

The characteristics of the vibration caused by the explosion in the regions close to the shot point are also affected by the blasting process especially the quantity of explosives used per delay time, the hole diameter, the sub-drilling distance, the spacing distance and the burden distance. Farther away from the shot point, the characteristics of the ground vibration are more affected by the geological formations and properties of the rock. Therefore, the peak particle velocities, vibration frequency, and field coefficients are also important and determinative factors in the occurrence of damage to buildings [3-4].

Frequency of vibrations generated by the blasting varies depending on the space and the geology of rocks (rock types) in the blasting area. The resulting vibrations will increase the likelihood of damage to buildings as they generate significant displacements and unit deformations at the frequency of less than $10 \mathrm{~Hz}$. If the generated vibrations generate frequencies lower than $10 \mathrm{~Hz}$, they will increase the probability of damage to buildings because they will cause significant displacements and unit deformations on the ground. The damage occurs as a result of blasting depends on the relationship between the frequency of the vibration waves generated on the ground and the natural (self-structuring) frequency of the building to be affected by vibration. The damage potential to buildings lower than the two-stories usually occurs in the range of $5 \mathrm{~Hz}$ to $10 \mathrm{~Hz}$ 
or more, which is the natural frequency value of the two-story building in the frequency of vibration occurring in the blasting event. In this case, the building enters resonance and the building continues to vibrate, even though the vibration wave on the ground has passed. When the building enters resonance, if the generated peak particle velocity (PPV) is at a value well below the specified limit value, people will be disturbed even if there is no damage to the building. On the other hand, if the peak particle velocity is too large (amplitude), damage will occur to the building [4-6].

As result of blasting, it is desired that the particle velocity with respect to the displacement $(\mathrm{cm})$ and ground acceleration $\left(\mathrm{cm} / \mathrm{sec}^{2}\right)$ for specific particle velocity is within certain limits to avoid the resonance. The propagation of vibration waves depends on the structural geology (faults and fractures etc.) of the area and the elastic properties of the ground (mechanics). If the ground in which the blasting is made is homogeneous, the speed of the seismic wave (vibration) usually fades at a far certain distance. Seismic wave velocities are directly related to the state of the geological discontinuities such as layer plane, fault state and joint structure of the ground. While seismic waves travel in the different discontinuities, it is difficult to determine the distances of the damping because fractures occur and reflections due to discontinuities [4-6].

The geological and geotechnical conditions of the rocks cannot be changed, but the quantity of explosives used per delay time can be estimated by the experimental formula and it is being suggested for blasting design. Various investigations have been done in the past to isolate environmental problems caused by blasting. Due to the complexity of the blasting phenomenon, there is no general reliable approach or formula yet. The complexity of blasting parameters and site factors limits the development of a general criterion in addition to the characteristics of the seismic wave and ground vibration, and studies specific to the site must be carried out to predict and control blasting effects [7-8].

Howkins (1961)[9], Cook (1992)[10], Jimeno et al. (1995)[7], Bohloli (1997) [11], Uyar and Bilgin (2004)[12], Karakuş (2010)[13], Deniz and Deniz (2015b)[14] investigated whether or not the blasting is related to the rock structure and they stated that the blasting is directly related to rock properties.

Furthermore, duration of the ground vibration is also very important in the blasting. For example; low-amplitude but longtime vibrations can be more damaging on the buildings than high-amplitude but short-time vibrations. Therefore, when designing blasting in nearby quarries, especially in villages and vineyards, it is necessary to make good arrangement with the geometry of the blasting hole and delay elements so that the vibrations can be reduced both by less than $3 \mathrm{~mm} / \mathrm{s}$ and by the ground vibration duration being short.

Mingsheng and Jianhua (2011)[15] conducted a series of tests on the effects of surface delays on ground vibration and frequencies. They indicated that surface delays were effective in blasting. They obtained the lowest frequency values with surface delays of $25 \mathrm{~ms}$ and $100 \mathrm{~ms}$ as a result of their work with surface delays of $25 \mathrm{~ms}, 42 \mathrm{~ms}, 50 \mathrm{~ms}$ and $100 \mathrm{~ms}$.

Shi and Chen (2011)[16] had been observed a similar effect in their study of the effect of delay time on blasting. A result of the test of the surface delay time from $15 \mathrm{~ms}$ to $40 \mathrm{~ms}$ with a difference of $5 \mathrm{~ms}$, the lowest ground vibration in the surface delays of $15 \mathrm{~ms}$ and $40 \mathrm{~ms}$ were reached.

In this study, a site application, in which surface delay times of $17 \mathrm{~ms}$ and $25 \mathrm{~ms}$ were applied from hole to hole using non- electrical (NONEL) capsules, was performed for ground vibration, an important environmental factor in blasting.

\section{Working Region}

A quarry of the Corum Votarantim Cement Factory, which is the study site, is located $5 \mathrm{~km}$ southeast of the city center of the Corum province (Figure 1). It is $1500 \mathrm{~m}$ south of the CorumSamsun road, $2100 \mathrm{~m}$ southeast of the cement factory, $1100 \mathrm{~m}$ east of the Melikgazi vineyards (Figure 2), 1400 m north-east of the Disaster Housing, 500 m east of the Municipality Quarry's building sites. In addition, the satellite image of the places whereof the points of measurements, the locations of the Municipality quarry's building sites and the Melikgazi vineyards, which is the nearest settlement, are shown in Figure 3.

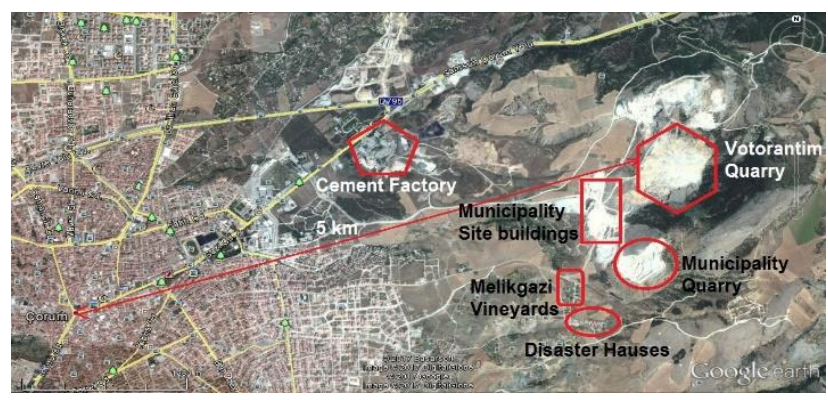

Figure 1. Satellite image of work area

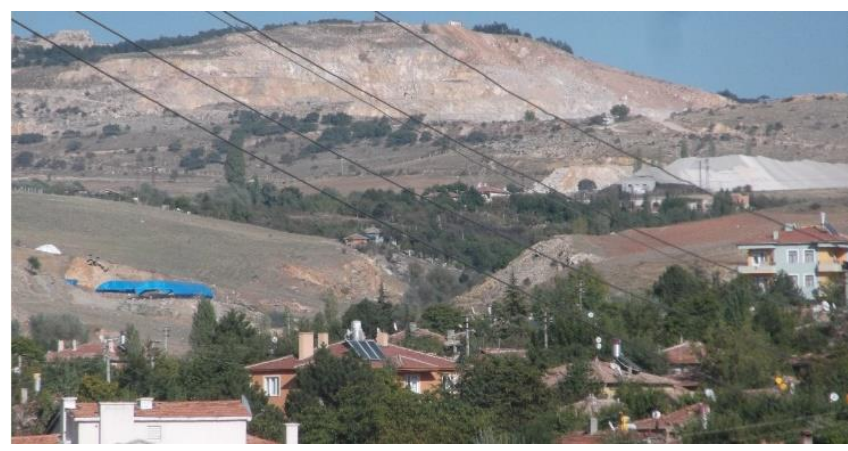

Figure 2. View of the distance between the study area and the Melikgazi vineyards which is the nearest settlement

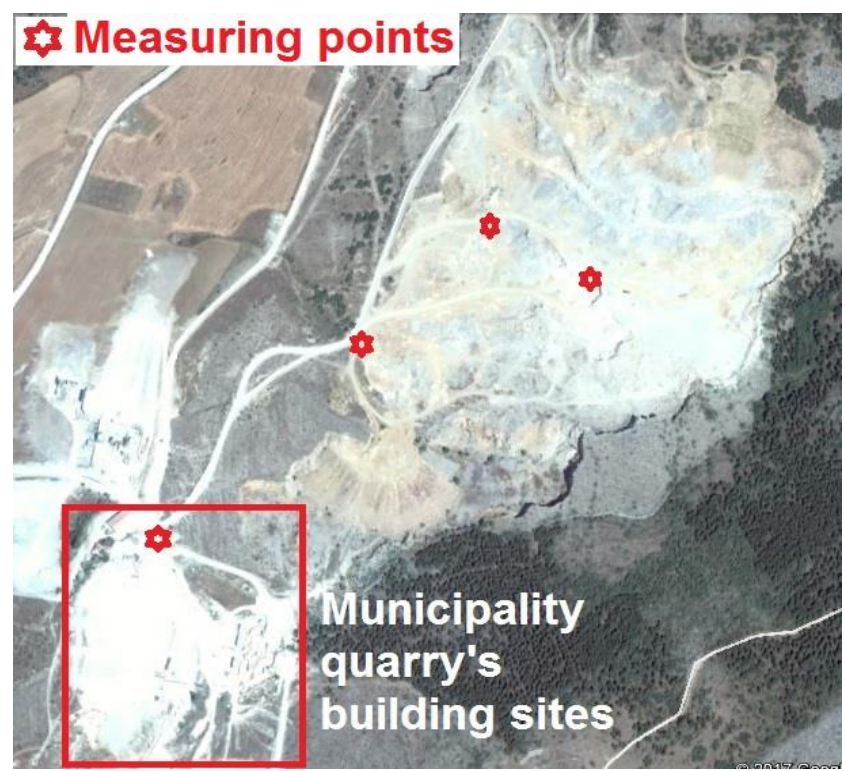

Figure 3. View of the measuring points 


\section{Research Method}

In this study, an evaluation was performed for the environmental impacts of the ground vibration values for the two different delay times of the blasting in the quarry of the Corum Votorantim Cement Plant, near the city center of the Çorum province. There are 7 stages, production made in the blasting operation in the quarry, and the height of each stage is almost equal and $10 \mathrm{~m}$. Drilling of blast holes was carried out with a Furukawa brand drill machine.

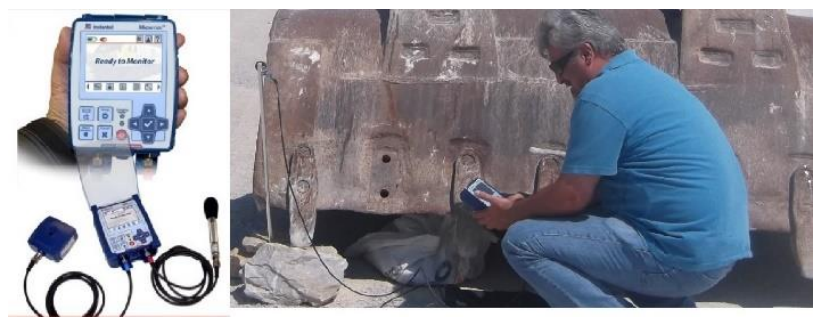

Figure 4. View of the vibration and air shock meter (seismometer) and installation of the seismometer instrument

In many studies; it is stated that the best estimation of peak particle velocity can be obtained as a result of observation of real shots due to changes in geometric and geological conditions of the blasting area. In result of many experimental work-outs that there is most reliability in the relationships based on the scaled distance (SD) and peak particle velocity (PPV). The concept of the scaled distance (SD) has been established in the relation to the amount of ground vibration, which occurs due to the amount of explosives directly affecting the particle velocity value at different distances between the shot point and the measuring point. The total energy that creates vibration movements in the ground varies according to the amount of explosives used per delay. The seismic waves starting from the point of shot spread out as it moves away from the point of shot and the volume of rock exposed to the pressure wave effect is increased. The scaled distance (SD) is derived from a combination of the amount of explosives used for each delay time affecting the formation of the ground vibration and the air shock power, and the distance between the shot point and the measurement point [17-20].

For the determination of the scale distances (SD) for ground vibrations, the square root equation given in Equation 1, which is widely used in many similar investigations, has been utilized [17].

$\mathrm{SD}=\mathrm{R} / \mathrm{W}^{1 / 2}$

where;

$\mathrm{R}$ : distance $(\mathrm{m})$

$\mathrm{W}$ : maximum charge per delay time $(\mathrm{kg})$

SD: Scaled distance $\left(\mathrm{m} / \mathrm{kg}^{1 / 2}\right)$

Pre-determination of vibrations caused by blasting is of great importance in preventing damaged to buildings. The result of many researchers it has been concluded that the estimate method, the peak particle velocity (PPV) from the scaled distance (SD) was the best for many researchers. The empirical relationship established for estimating the peak particle velocity (PPV) depending on the scaled distance (SD) is given in Equation 2 [5].

$\mathrm{PPV}=\mathrm{K} *(\mathrm{SD})^{-\beta}$

where;
PPV: Peak particle velocity distance $(\mathrm{m} / \mathrm{s})$

\section{$\mathrm{K}, \beta$ : Site constants}

In this study, the risk analysis of damage caused by blasting done in the working area; With the equation given in Equation 2, the German Norm (DIN 4150)[21], the USA Open Mining Bureau (OSM) norm (1983)[22], the USA Mining Bureau (USBM) Alternative Explosion Damage Criteria Norm (2009) [23] which is subsequently developed, and Environmental Hazard Assessment and Management Regulation (2010) [24] belongs to the Ministry of Environment and Forestry of Turkey were used.

In this study; 20 blasts with non-electric capsules were recorded by ground vibration instruments. As shown in Figure 5 , the places of the vibration meters (seismographers) were determined by GPS (Global Positioning System) as a systematic manner in the same direction as the shot points made in the Corum Votorantim Cement's quarry. The test shots were made as ten (10) for each two different surface delays $(17 \mathrm{~ms}$ and $25 \mathrm{~ms}$ ) by NONEL capsules as shown in Figure 6.

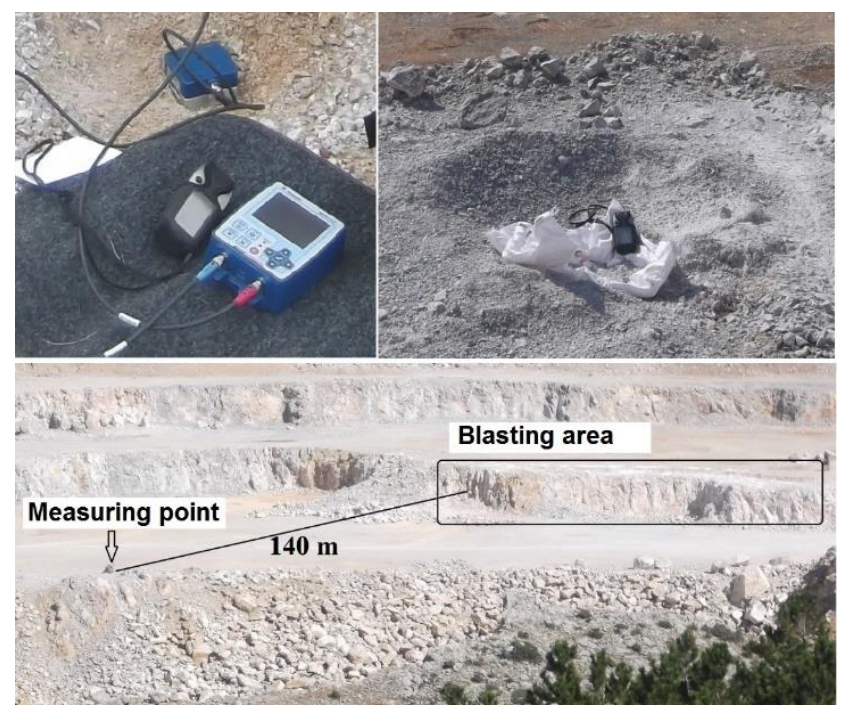

Figure 5. Determination of shot and measuring points by GPS

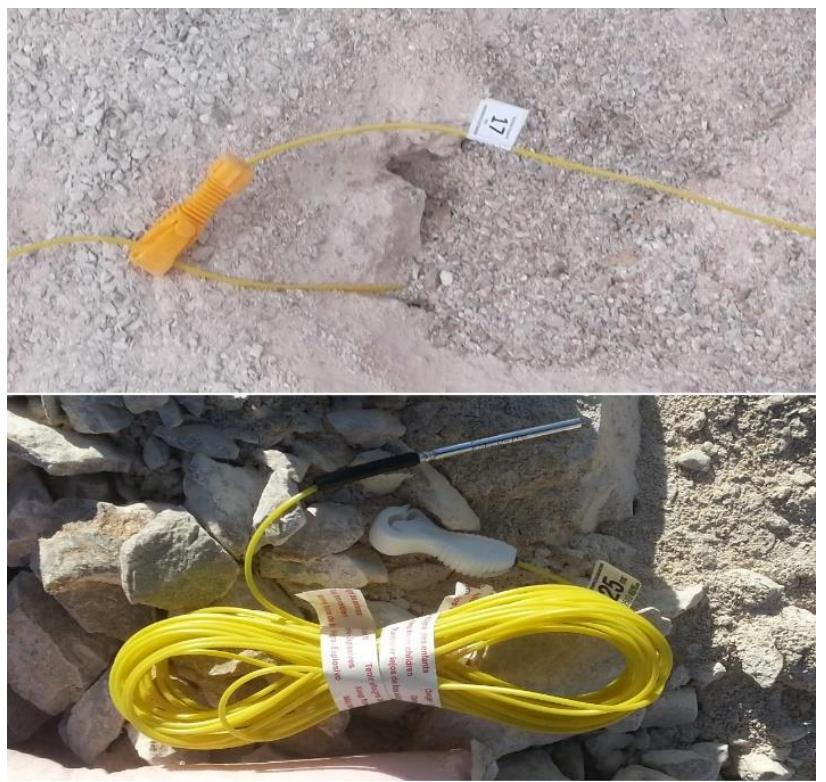

Figure 6. Non-electrical (NONEL) capsules with surface delay of $17 \mathrm{~ms}$ and $25 \mathrm{~ms}$, and bottom delay of $500 \mathrm{~ms}$ 


\section{Evaluation of Blasting Tests}

In the area applications, 80 blasting holes were opened being 18 or 22 pieces in 4 rows per each blasting. The bottom delay times of all blasting holes were $500 \mathrm{~ms}$, surface delay time between the rows was $42 \mathrm{~ms}$, surface delays between holes were $17 \mathrm{~ms}$ and $25 \mathrm{~ms}$, and there were made 10 the shots for both $17 \mathrm{~ms}$ and $25 \mathrm{~ms}$. In the area applications, the shape of the connection of the surface delays for the blasting made to investigate the effect of between holes surface delays is shown in Figure 7.

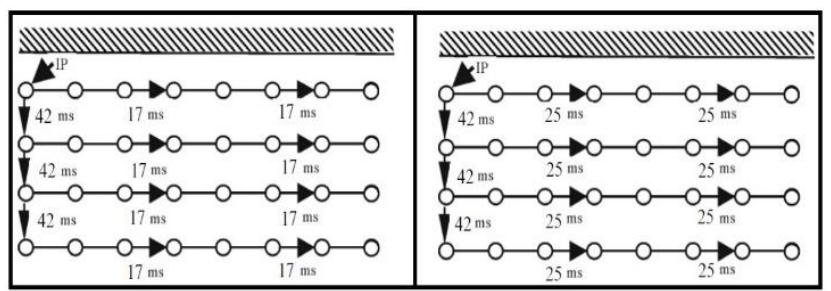

Figure 7. The connection of the ignition system for the surface delay of $17 \mathrm{~ms}$ and $25 \mathrm{~ms}$

In the scope of the research; 20 measurements taken from shots of 20 pieces for two different surface delays in the Çorum Votorantim Cement's quarry were taken into evaluation. A surface delay of $17 \mathrm{~ms}$ was applied to 10 of these 20 shots while a surface delay of $25 \mathrm{~ms}$ was applied to the other 10 holes. To determine the peak particle velocity, the relationships between the peak particle velocity (PPV) and the scaled distance (SD) were investigated based on the maximum amount of explosive per surface delay time and the distances between the shot and the measurement points. The Microsoft Excel program was used in order to determine the relationship between the measured peak particle velocity (PPV) and the scaled distance (SD) for both surface delay times, and the relationships found in the regression analysis are given in Equation 3 and Equation 4.

$\mathrm{PPV}=180.45 *(\mathrm{SD})^{-1.3236}$

$\mathrm{PPV}=3056.50 *(\mathrm{SD})^{-1.9493}$

A graphical representation of the estimate equations obtained for the PPV and the SD for both surface delays (regression coefficients for $17 \mathrm{~ms}$ and $25 \mathrm{~ms}$ are $r^{2}=0.9605$ and $r^{2}=0.9878$, respectively) are given in Figure 8. As can be seen from Figure 8 , it has been found that the surface delays between $17 \mathrm{~ms}$ and $25 \mathrm{~ms}$ are relatively different. It has been understood that if the distance between the point of shot and the point of measurement is increased, the effect of the surface delay is not important, and it is more related to the rock structure that is known from previous research. The closer the distance between the shot point and the measuring point, the more important the surface delay is. However, it is beneficial to increase the number of measurements at the selected nearest point between the point of measurement and the measuring point in order to make this conclusion a final judgment. In addition, it is necessary to make a definite decision after conducting studies involving not only 17 and $25 \mathrm{~ms}$ surface delays but also $42 \mathrm{~ms}$ and $63 \mathrm{~ms}$ surface delays. Future studies are aimed at the detailed study on this subject.

In additionally, the peak particle velocity (PPV) and the corresponding vibration frequency $(\mathrm{Hz})$ values measured at all shots for surface delays of $17 \mathrm{~ms}$ and $25 \mathrm{~ms}$ between the holes were determined according to norms of the German DIN 4150 [21], USA-OSM [22], USA-USBM [23] and the Ministry of Environment and Forestry (Turkey) [24], and are shown on the graph in Figure 9.

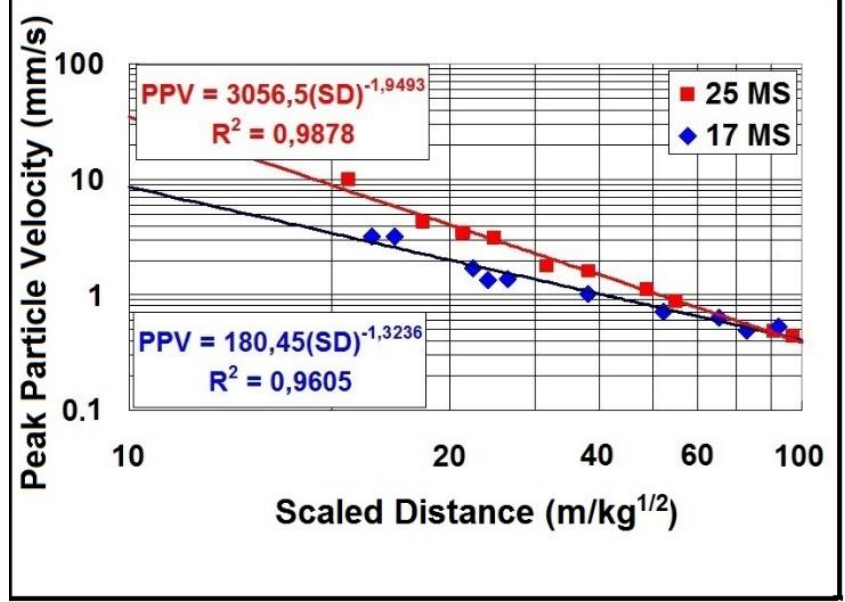

Figure 8. Relationships between the scaled distance (SD) and the peak particle velocities (PPV) obtained at $17 \mathrm{~ms}$ and $25 \mathrm{~ms}$ surface delays

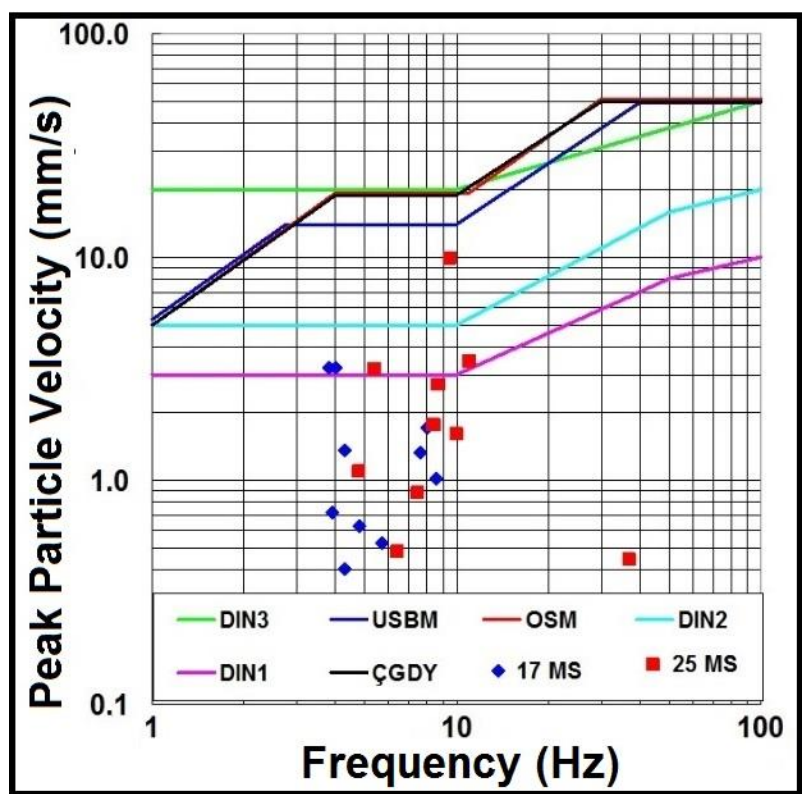

Figure 9. Relationships between the peak particle velocities (PPV) and the frequency (Hz) values obtained by the shots with the surface delays of $17 \mathrm{~ms}$ and $25 \mathrm{~ms}$.

When the positions of the peak particle velocity (PPV) and the vibration frequency $(\mathrm{Hz})$ in Figure 9 are examined on the graphs, all of the shots according to the measuring points are compared to the USA-OSM (1983)[22], USA- USBM (2009)[23] and the Ministry of Environment and Forestry (Turkey)(2010)[24] it is understood that it is below the damage limit. It only appears to have crossed the limits according to German DIN 4150-1 and DIN 4150-2 (1983) [21]. When the shots exceeding the limits were examined, it was observed that the measured points were within the quarry and there was no risk of damaging the Melikgazi vineyards at a distance of about $1100 \mathrm{~m}$. It is understood that the measured ground vibration values cannot be effective in terms of creating damage to the construction site buildings belonging to the Çorum Municipality's quarry and in the Melikgazi vineyards according to the related national and international norms. In addition, the shots showed different relationships between the PPV and the frequency dependence for surface delays of $17 \mathrm{~ms}$ and $25 \mathrm{~ms}$ between the holes. The surface delays of $25 \mathrm{~ms}$ had provided higher particle velocities and relatively higher frequencies 
compared to surface delays of $17 \mathrm{~ms}$. In this case, the surface delay of $25 \mathrm{~ms}$ gives a more acceptable view in terms of damage to the buildings and the feeling of disturbing people.

We know that the duration of vibration is also very important in blasting and that low-amplitude but long-time vibrations can be more damaging than high-amplitude but short-time vibrations. The samples of the seismograph prints for two
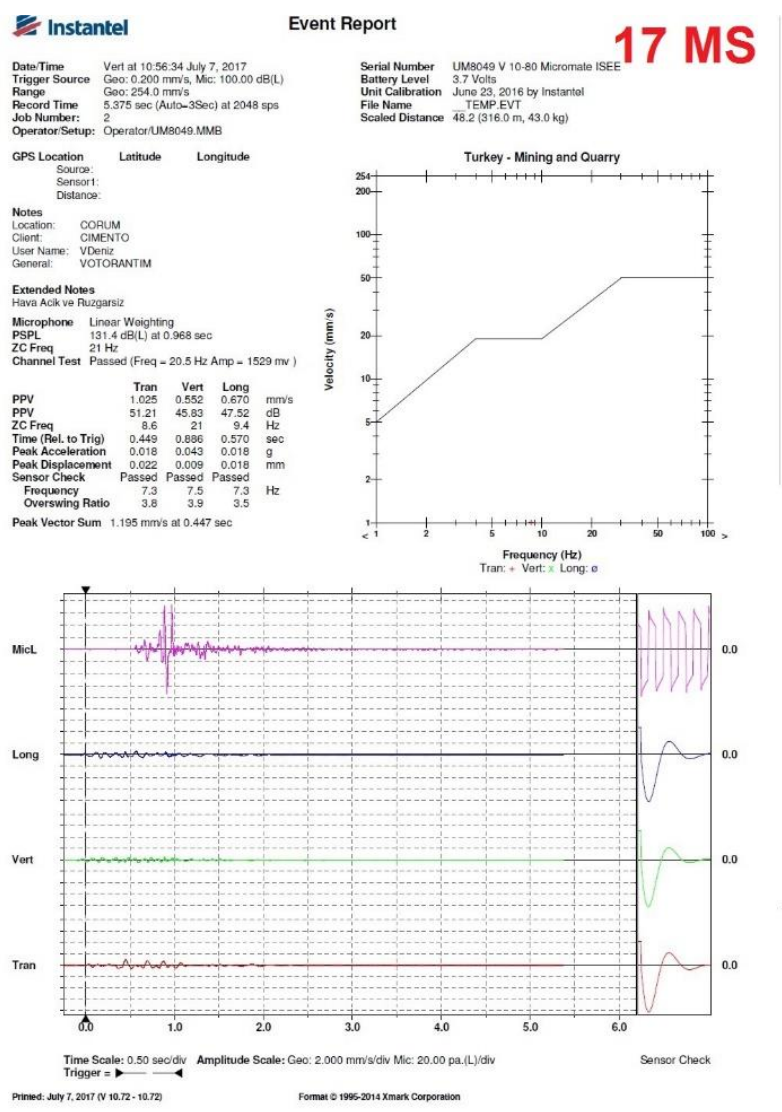

different surface delays (17 $\mathrm{ms}$ and $25 \mathrm{~ms}$ ), which are approximately the same the distance between the shot point and the measured point, are given in Figure 10. As can be seen from Figure 10, the vibration duration is more time and the amplitude is lower than the surface delay of $25 \mathrm{~ms}$ of the seismic waves obtained by the surface delay of $17 \mathrm{~ms}$. In this case, it has been shown that surface delay of $25 \mathrm{~ms}$ for the same vibration period is more suitable for damage potential.

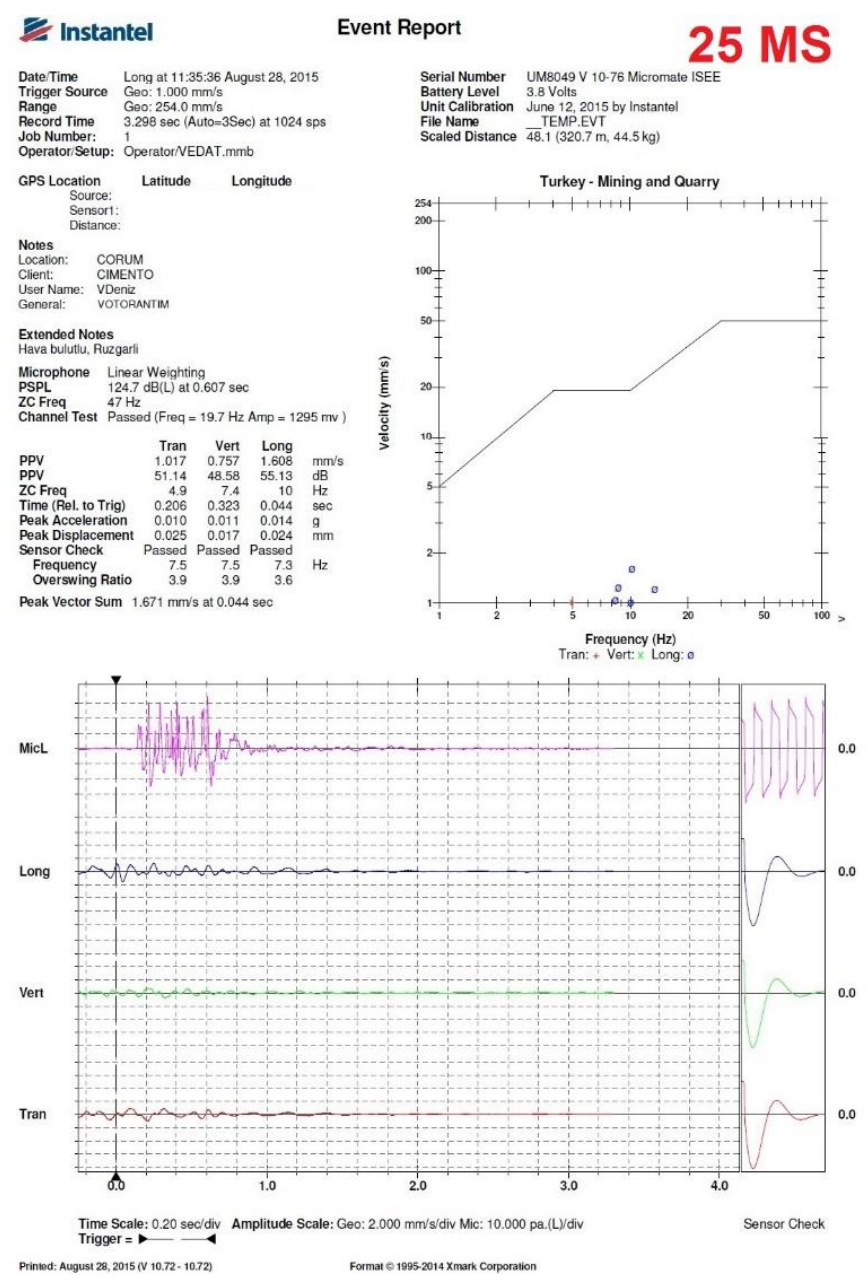

smometer recorder by the blasting with surface delays of $17 \mathrm{~ms}$ and $25 \mathrm{~ms}$

The results of this study were different obtained from the results of Mingsheng and Jianhua (2011)[15] and Shi and Chen (2011)[16] studies. This study showed that the most appropriate surface delay could be different according to the rock structure of the quarry. Therefore, it has appeared that the blasting parameters for each quarry must be separately evaluated to lower the costs in the blasting process.

\section{Conclusion}

In the result of the investigation with the purpose of determining the effect of ground vibrations using two different surface delay times ( $17 \mathrm{~ms}$ and $25 \mathrm{~ms}$ ) between the holes;

- A total of 20 shots for each 10 for two different surface delay times between holes at different locations of the quarry were made of the quarry and recorded with a seismograph. The values of these measurements were obtained to the peak particle velocities (PPV) ranging from $0.402 \mathrm{~mm} / \mathrm{sec}$ to $9.936 \mathrm{~mm} / \mathrm{sec}$.

- In the investigation of the relationship between the Peak Particle Velocity (PPV) and the Scale Distance (SD) for two different surface delay times ( $17 \mathrm{~ms}$ and $25 \mathrm{~ms}$ ) between the holes, it has been found to be effective when near the distance between the shot point and the measuring point, while it has become less effective when the distance increases. With the increase of the distance, it is thought that it is more related to the rock structure and geology of the field.

- When the shots for two different surface delays are examined; it has been found that the vibration amplitudes obtained from the surface delay time of $17 \mathrm{~ms}$ are lower, while it is more risky for damage potential for relatively higher vibration duration. Therefore, it was predicted that usage of 25 ms surface delay in between holes would be better for this quarry.

- At the end of this study, it was found that, in order to shed light on future work, and it was necessary to again study very different delay times, to more numbers and to closer the distance between the shot point and the measurement point. 


\section{Acknowledgment}

This study was carried out with the research project (Project No: MU19005.15.01) under the 19005 University-Sector Cooperation supported by the Hitit University Scientific Research Fund (BAP).

In addition, we would like to thank the Corum Votorantim Cement Plant officials and employees for their assistance in the field works and other activities during this research.

A part of this manuscript is presented at ISME2017.

\section{References}

[1] Deniz, V. ve Deniz, O.T. "Çorum çimento taş ocağında yapılan patlatmaların çevresel etkiler açısından değerlendirilmesi", 5. Madencilik ve Çevre Sempozyumu, Antalya, 2015, 144-158.

[2] Deniz, V. and Deniz, O.T. "The environmental effects of the air shock generated by blasting", Mugla Journal of Science and Technology, Vol 3(2), 166-170, 2017.

[3] Dowding C.H. Blast Vibration Monitoring and Control, Prentice-Hall, USA, 1985.

[4] Bilgin, H.A., Esen, S. ve Kılıç M. "Patlatma kaynaklı yer sarsıntılarının binalar üzerindeki etkisi ve büyütme faktörünün önemi”, Türkiye 16. Madencilik Kongresi, Ankara, 1999, 25-32.

[5] Siskind, D.E., Stagg, M.S., Kopp, J.W. and Dowding, C.H., Structure response and damage produced by ground vibration from surface mine blasting, RI 8507, Bureu of Mines Report of Investigations, USA, 1980.

[6] Kahriman, A., Karadoğan, A.K., Görgün, S. ve Tuncer, G. "Taşocaklarında patlatmadan kaynaklanan yer sarsıntısının ölçülmesi ve analizi”, 2. Ulusal Kırmataş Seтроzуuтu, İstanbul, 1999, 129-142.

[7] Jimeno, C.L., Jimeno, E.L. and Carcendo, F.J.A., Drilling and Blasting of Rocks, AABalkema, Rotterdam, Brookfield, 1995.

[8] Kahriman, A., Karadoğan, A.K., Görgün S. ve Tuncer, G. "Açık ocak basamak patlatmalarından kaynaklanan yer sarsıntısı hızının tahmini: Çan linyit isletmesinde örnek bir çalışma", Türkiye 17. Uluslararası Madencilik Kongresi ve Sergisi-TUMAKS 2001, Ankara, 2001, 29-37.

[9] Howkins, L.V. "The reciprocal method of routine shallow seismic refraction investigations", Geophysics, Vol. 26, 809$819,1961$.

[10] Cook, N.G.W. "Natural joints in rock: mechanical, hydraulic and seismic behaviour and properties under normal stres", Int. J. Rock. Min. Sci. Geomech., Vol. 29, 198-223, 1992.

[11] Bohloli, B. "Effect of the geological parameters on rock blasting using the Hopkinson split bar", Int. J. Rock. Min. Sci., Vol.34(3-4), 032e1-032e9, 1997.

[12] Uyar Aldaş, G.G. and Bilgin, H.A. "Effect of some rock mass properties on blasting-induced ground vibration wave characteristics", CIM Bulletin, Vol. 97, 52-59, 2004.

[13] Karakuş, D. "Patlatmadan kaynaklanan titreşimlerin yönsel değișiminin araştırılması", Mühendislik Bilimler Dergisi, DEÜ Mühendislik Fakültesi, 12(2), 30-43, 2010.

[14] Deniz, V. ve Deniz, O.T. “Çorum Belediyesinin taş ocağında patlatma kaynaklı titreşimlerin yönsel açıdan değerlendirilmesi", 5. Madencilik ve Çevre Sempozyumu, Antalya, 2015, 159-174.

[15] Mingsheng, Z. and Jianhua, Z. "Changping Y. Timefrequency characteristics of blasting vibration signals measured in milliseconds", Mining Science and Technology, Vol. 21, 349-352, 2011

[16] Shi, X.Z. and Chen, SH.R. "Delay time optimization in blasting operations for mitigating the vibration-effects on final pit walls' stability", Soil Dynamics and Earthquake Engineering, Vol. 31, 1154-1158, 2011.

[17] Duwall, W.I and, Fogleson, D.E. Review of criteria for estimating damage to residences from blasting vibration, USBM-I 5968, USA, 1962.

[18] Ambraseys, N.R. ve Hendron, A.J. "Dynamic behavior of rock masses", Rock Mechanics in Engineering Practice, Stagg, K.G. and O.C. Zeinkiewicz. Wiley, London, 1968, 203227.

[19] Langefors, U. and Kihlstrom, B. The Modern Technique of Rock Blasting, Wiley Publisher, New York,USA, 1973.

[20] Birch, W.J. and Chaffer, R. "Prediction of ground vibrations from blasting on opencast sites", Trans. Inst. Min. Metallurgy, Vol.4, 103-107, 1983.

[21] DIN 4150, "Structural vibration in buildings. Part 3: Effects on structures", German Standards Organization (GSO), Berlin, Germany, 1999.

[22] OSM (OSMRE), Rules and Regulations, Use of Explosives, Federal Register, Vol. 48(46), March 8, 9788-981146, USA, 1983.

[23] USBM RI 8507, Structure response and damage produced by ground vibration from surface mine blasting, Report No. RI 8507, Washington, USA, 2009.

[24] ÇSB, "Çevresel Gürültünün Değerlendirilmesi ve Yönetimi Yönetmeliği”, T.C. Çevre ve Şehircilik Bakanlığı, Ankara, 2010 